\title{
A POPULIST MOMENTUM IN THE EU?
}

\section{Robert Adam,}

Ph. D. in Political Science, Université libre de Bruxelles robertadam_99@yahoo.com

\section{DOI:10.24193/OJMNE.2017.23.02}

\begin{abstract}
Populism is one of the most used terms in political discourse, most often with a pejorative connotation, but the meaning of the term is ambiguous. The European public opinion thinks populism is on the rise in the EU. Can we therefore speak of a populist momentum in Europe? In order to answer this question, we need to clarify a few preliminary aspects: what is populism? Is there a conceptual framework of populism? What parties can be labelled populist and on what grounds? Is an anti-EU or anti-immigration stance enough to label a party populist? Inside the EU, is Western populism similar to its Eastern variety? Which would be the accurate threshold to ascertain that populism is more successful now than 5 or 20 years ago at the EU scale?
\end{abstract}

Keywords: populism, EU, parties, elections, Euroscepticism.

We argue that populism is a concept with a long history and provide a definition of populism allowing us to draw a list of European populist parties and review their recent performance in European Parliament and national legislative elections. In our view, there is no divide between Eastern and Western European populism, only minor contextual differences. If we are to speak about a populist momentum, it is not necessarily by virtue of the cumulated populist score. The major factor is the new status that populism has managed to acquire following the 2004 and 2007 successive EU enlargements. Unlike in Western Europe, in Central and Eastern Europe populist parties become mainstream and won the elections (in Hungary, Poland, Slovakia).

If there is one ubiquitous word in the political vocabulary, then it must be populism. Politicians, pundits, academics, economists, the media incessantly use it. Undoubtedly, the term has a pejorative connotation. It has almost grown into a synonym for demagoguery.

The general perception is that populism in the EU is on the rise. Can we therefore speak of a populist momentum in Europe? In order to answer this question, we need to clarify a few preliminary aspects: what is populism? Is there a conceptual framework of populism? 
Issue no. $23 / 2017$

What parties can be labelled populist and on what grounds? Is an anti-EU or anti-immigration stance enough to label a party populist? Inside the EU, is Western populism similar to its Eastern variety? Which would be the accurate threshold to ascertain that populism is more successful now than 5 or 20 years ago at the EU scale?

\section{Populism: an ambiguous concept}

If everyone seems to talk about populism, is there a consensus on the meaning of the term? By no means: if there be an arduous conceptual task, then it must be defining populism. Populism is a vague concept and the word is used almost exclusively in a negative context. Nevertheless, for more than 50 years, a rather rich literature has tackled the subject.

The stumbling block has most often been the ambiguity of the term populism. Is it an ideology or a movement? Also, as populism has mostly been defined by delimitation, by its critics rather than by its followers, this has created a wider spectrum of signification. This illegitimate birth entails a limited conceptual autonomy: populism needs to be compared to something else in order to be identified a contrario. Also, populism has often been considered a disease of representative democracy, not a doctrine in its own right.

This has not always been the case. Populism is the iron mask of democracy, the supplanted twin. Populism does have a legitimate history: people used to proudly call themselves populists and defended their political vision.

The concept of populism has been drawing the attention of social scientists for exactly half a century. The first academic symposium dedicated to populism was held on May 19-21 at the London School of Economics and its works were subsequently published in 1969 (Ionescu and Gellner, 1969).

But in order to trace the academic history of populism, one needs to follow its political history.

Populism and democracy share their roots. Populism and the nation-state were born at the same moment in history: the end of the $18^{\text {th }}$ century which brought about the French Revolution. Representative democracy won over populism as the political regime of the newborn nation-state. The people is the new sovereign, only it does not rule directly but via elected representatives. The transition was operated during the Estates-General in 1789, when the Third Estate breaks away and establishes itself as National Assembly instead of People's Assembly: the people vanishes, the nation supersedes it. The second half of the $19^{\text {th }}$ century sees it resurface in Russia and the US, with the narodniki and the American populists. 
Issue no. 23/2017

The narodniki were left-wing intellectuals opposed to the reforms meant to westernize Russia. Their doctrine blended socialism and tradition, and the role of the intellectuals was to enlighten the peasants. Strongly anti-capitalist, they dreamt of a new society built upon the model of the traditional Russian rural community, with its collective ownership of the lands. The movement was active between 1850 and 1880, and in 1876 the party Zemlia $i$ Volia (Land and Freedom) was founded. Internal disputes led to a split. The radical terrorist wing disintegrated after the assassination of Tsar Alexander II (1881).

In the US, the impulse of the populist movement did not come from the elite, but from the farmers themselves. The Farmers' Alliance, set up in 1876, was the reaction of Southern and Western farmers to the agricultural crisis of the mid 1870's. Facing low prices and mounting debts, under pressure from banks and railroads, they lobbied the federal government for regulation. As the Republican and Democrat parties were reluctant to the farmers' requests, in 1891, the People's Party, widely known also as the Populist Party, was created. Its goal was to defend the interests of the small farmer against the financial and industrial elite. As such, it advocated for the dismantling of national banks, a graduated income tax, direct election of US senators and Government control of all railroads, telegraphs and telephones.

At the 1892 presidential election, the People's Party candidate carries four states. The populists are also the first American party to accept women members. Four years later, the party decided after a lively convention to support the losing Democrat candidate. In 1900, 1904 and 1908, the party runs the presidential race. Governors, senators and congressmen were elected under its banner before the party collapsed. Nevertheless, the populist left their mark on the American political history by their appeal to increase the federal power in order to turn it into "the people's government". If their beliefs were often related to socialism, they were not socialists in their vision of private property as principle of economy. One of the key factors contributing to the transformation of Southern farmers' discontent into political populism was their engagement in the co-operative movement (Canovan, 1981, p. 54). This pattern is also visible in the second wave of political populism: Eastern European populism in the interwar period. The People's Party is already typical for a major identity problem of populism: its ambiguous position on the left-right axis.

Eastern European populism is also known as the Green Uprising. Agrarian parties met massive success in Bulgaria, Czechoslovakia, Poland, Romania and Yugoslavia. The ideology of these parties highlights private property, land reform and co-operativism and 
their usual nemesis are banks and big landlords. Nationalism is embedded in the DNA of these movements and they advocate for their people's emancipation from foreign domination and the right of the peasantry to build a society mirroring its conservative views.

The following historical waves were Latin American populism, Western European protest movements of the 1980's and 1990's and the new Eastern European populisms. 50 years of populism studies converge on only two distinctive feats shared by all populisms:

a) trust in the people;

b) anti-elitism.

Nevertheless, if these two characteristics are common to all forms of populism, they are not its exclusive prerogative. Other political visions, such as libertarianism, socialdemocracy or even Christian-democracy might well claim them in turn. Therefore the conjunction of these two features does not suffice for a minimal definition of populism. Yet the archetypal populist discourse amounts to mobilizing the virtuous common people against the corrupt elites. Considering populism a discourse in the sense given by Ernesto Laclau allows us to avoid the movement/ ideology dichotomy. So, after extensive research we have drafted the following definition of populism integrating elements from Hélio Jaguaribe, Guy Hermet, Daniele Albertazzi \& Duncan McDonnel:

Populism is the discourse rallying the people against a set of leading elites which would deprive (or attempt to deprive) the sovereign people of its rights, values, prosperity, identity and voice and which pretends to possess an instant remedy to the problems of a given society (Adam, 2016).

\section{What populist parties in the EU?}

In order to assess if there is or not a populist momentum in the EU, one needs to identify which are the populist parties referred to. The definition we have designed shall provide instrumental, as elements of populist discourse have been integrated in the political messages of parties across the political spectrum. We consider that, in order to be relevant, populist movements have to be or have been represented in Parliament over the last five years. As some countries do not have a proportional electoral system, one has to allow for parties with a significant share of voter support but little or no MPs, so we set an alternative significance threshold at $5 \%$ of the votes cast in a national election. For instance, UKIP currently has no MP in the newly-elected British parliament, but came first in the UK at the 2014 European Parliament elections. 
Issue no. 23/2017

The list of populist parties in the EU below can undoubtedly be disputed. Other parties not picked in this table have also been labelled populist by social scientists. Among those included, some are members of mainstream European parties (Direction-Social Democracy in the Party of European Socialists, Fidesz in the European People's Party). In Bulgaria, Boyko Borisov's GERB, member of the EPP, is often considered populist. From our point of view, it is a centre-right party with populist propensity. There is no Romanian representative, as Dan Diaconescu People's Party, the third political force following the 2012 general elections, ceased to exist in 2015. The Greater Romania party, which enjoyed considerable electoral success in 2000 and 2004, has also collapsed, so that for the time being there is no populist movement in the country. In Greece, Golden Dawn has sometimes been called populist: we envisage it as a far-right movement. In Cyprus, the Citizens' Alliance (SYPOL) is also regarded at times as populist: we deem it a radical left party. The Kotleba People's Party Our Slovakia does not qualify in our view to be considered right-wing populist, as there is solid ground to place it to the extreme right. Nine EU countries momentarily lack a successful populist actor: Croatia, Cyprus, Estonia, Latvia, Luxembourg, Malta, Portugal, Romania and Slovenia.

The ideological diversity of the selected parties is extreme, ranging from the far left (SYRIZA, Die Linke) to the far right (AfD, Jobbik), corroborating the idea that populism is neither right nor left. As compared to our definition, all these parties rally the people against distant elites, most often the European Union, but also the national establishment perceived as alienated from the people's needs and aspirations (FN, AfD, M5S, Unidos Podemos, UKIP). For the most left-leaning, these corrupt elites represent the capitalist system (Die Linke, SYRIZA). Some of them, as current (SYRIZA, PiS, Smer-SD, Fidesz) or former (FPÖ) ruling parties, and even as junior coalition partners (SNS, United Patriots), cannot fully play the anti-establishment card, so they resort to the unifying populist rhetoric. Unifying populism serves politicians trying to transcend cleavages, to pose as connectors. To do so, they make use of a semantic ambiguity of the term people, which can signify altogether the people as nation (dêmos), the ethnical people (ethnos) or ordinary people. Thus they can appeal to the people to seek unity for a wide range of purposes, the only constant being that the foreseen unity is made against something: the other politicians and parties if the intended audience is the people of citizens, the civic nation (dêmos); the foreigners, be they from outside the country or from within (minorities) if they address the ethnic people 
Issue no. $23 / 2017$

(ethnos); the wealthy and all sorts of elites if one intends to rally the grassroots against the powerful.

When Orbán Viktor developed the concept of illiberal democracy, it was in fact a populist democracy that he was advocating for. A democracy where supranational elites cannot sway national policies; where checks and balances are limited and the government has a strong say in economy; where the people achieves self-government and the political agenda is regulated by instruments of direct democracy (referenda). As a role-model populist, the Hungarian prime minister was disputing the theory of elitarian democracy to be defended against the people unable to grasp its level of complexity as a political system, famously elaborated by Lipset (1960).

The EU is the ideal scapegoat for populist parties, but they do not have the monopoly of Euroscepticism. Mainstream European parties, such as the British Conservatives, have been very critical of EU policies. According to their attitude towards the EU, the populist parties can be divided into hard and soft Eurosceptics. Hard Eurosceptics (Europhobes) would rather their country withdrew from the EU, while soft Eurosceptics plead for EU reform. The tough stance is roughly shared by UKIP, the National Front, the Italian 5 Star Movement, Danish People's Party, Jobbik, the Lithuanian Order and Justice, the Dutch Party for Freedom, the Sweden Democrats, part of the United Patriots electoral alliance from Bulgaria (Ataka) and the Vlaams Belang. The rest are rather to be placed on the soft Euroscepticism side.

Not surprisingly, the pro/anti-EU cleavage is most important in the European Parliament elections and less important in national ones. Some of the most Europhobic parties (UKIP, National Front, Order and Justice, the Danish People's Party) have posted massive scores in the EP polls, at least twice their tally in the national legislative ballot.

A key element when it comes to sorting which parties can be counted as populist stems from the third part of our definition ("instant remedy"). The issue is the relationship to time. The time of populism is the present continuous or the historical present. The populist speaker devises, by an emotional discourse bordering on the uchronia, an artificial time in which the historical figures from the past are called to weigh in today's political decisions. This feature is shared with nationalism. If populism can foster social and economic transformation, as it did in Latin America, the values it carries are traditional and its essence is not revolutionary. In order to overcome this dichotomy, populism needs to adopt a historical perspective. 
For Guy Hermet (2001, p. 50), this particular relationship to the political time is at the very core of populism . Populism pretends to possess immediate solutions to long-term problems. Pierre-André Taguieff (2001, p. 406) places the time of populism in a magical dimension: "The time of populism is a mythical time, and populist action has a lot to do with political magic."

Most of the parties in the table have made use of the instant remedy policy to lure voters (United Patriots, Volya, FN, SYRIZA, Jobbik, M5S, PVV, Smer-SD, SNS, Unidos Podemos being the most conspicuous and consistent in this practice). This tactic is all the more effective as the party is certain not to be able to take office, but some of these parties eventually did, which led in the aftermath to a more cautious approach (SYRIZA, Smer-SD).

UKIP's and Leave campaign's pledge to redirect $£ 350$ million per week from UK’s net contribution to the EU budget towards the British National Health Service was one of the most powerful arguments for the Brexit vote in the 2016 referendum. Upon victory, nobody backed this promise anymore, as it turned out the figure was grossly inaccurate. In the ensuing national elections in June 2017, the UKIP crashed at $1.8 \%$, down from $12.6 \%$ in the 2013 legislative polls and $27.5 \%$ in the 2014 EP elections.

EU populist parties' results in the 2014 European Parliament elections and last national elections

\begin{tabular}{|l|l|l|l|l|l|}
\hline Country & Populist Party & $\% \mathrm{EP} 14$ & $\%$ Nat & Rank & $\%$ Change \\
\hline Austria & Austrian Freedom Party (FPÖ) & 19.7 & 20.5 & 3 & +1.5 \\
\hline Belgium & Flemish Interest (Vlaams Belang) & 4.1 & 3.7 & 10 & -5.7 \\
\hline Bulgaria & United Patriots & & 9.0 & 3 & - \\
\hline Bulgaria & Volya & & 4,1 & 5 & - \\
\hline Czech Rep & Dawn of Direct Democracy & 3.1 & 6,9 & 6 & - \\
\hline Denmark & Danish People's Party & 26.6 & 12.3 & 2 & -1.6 \\
\hline Finland & Finns Party & 12.9 & 19.1 & 2 & -1.4 \\
\hline France & National Front (FN) & 25.0 & 13.2 & 3 & -0.4 \\
\hline Germany & Alternative for Germany (AfD) & 7,1 & 12,6 & 3 & +7.9 \\
\hline Germany & The Left & 7.3 & 9.2 & 5 & +0.6 \\
\hline Greece & Coalition of the Radical Left (SYRIZA) & 26.6 & 35.5 & 1 & -0.8 \\
\hline Hungary & Fidesz - Hungarian Civic Union & 51.5 & 44.5 & 1 & -4.3 \\
\hline Hungary & Movement for a better Hungary (Jobbik) & 14.7 & 20.2 & 3 & +3.5 \\
\hline
\end{tabular}


Issue no. 23/2017

\begin{tabular}{|l|l|l|l|l|l|}
\hline Ireland & Sinn Fein & 19.5 & 13.8 & 3 & +3.9 \\
\hline Italy & Five Star Movement (M5S) & 21.2 & 25.6 & 1 & +5.6 \\
\hline Lithuania & Order and Justice & 14.3 & 5.6 & 7 & -1.7 \\
\hline Netherlands & Party for Freedom (PVV) & 13.2 & 13.1 & 2 & +3.0 \\
\hline Poland & Law and Justice (PiS) & 31.8 & 37.6 & 1 & +7.7 \\
\hline Slovakia & Direction-Social Democracy (Smer-SD) & 24.1 & 28.3 & 1 & -16.1 \\
\hline Slovakia & Slovak National Party (SNS) & 3.6 & 8.6 & 4 & +4.1 \\
\hline Spain & United We Can (Unidos Podemos) & 8.0 & 21.2 & 3 & -3.3 \\
\hline Sweden & Sweden Democrats (SD) & 9.7 & 12.9 & 3 & +7.2 \\
\hline UK & UK Independence Party (UKIP) & 27.5 & 1,8 & 3 & -10.8 \\
\hline
\end{tabular}

\section{Eastern vs. Western populism}

As populism is not an ideology, insofar it is unable to provide a comprehensive worldview, and very few parties acknowledge a populist vision, it is an uphill task to gather parties from countries with diverse national contexts under this label. One of the recurrent issues has been the East/ West divide: is the populism of former communist countries in Central and Eastern Europe the same political phenomenon as the one in Western Europe? As the public opinion in Central and Eastern Europe (CEE) is rather positive about the EU (according to the Eurobarometer 87 - Spring 2017, 10 out of 11 CEE audiences profess more trust in the EU than the EU28 average), can populist parties in these countries be as Europhobic as the Western ones and still make electoral breakthroughs? Anti-immigrant discourse is a must for Western populist parties. The CEE is hardly a destination for immigration, on the contrary, millions of Eastern Europeans have turned the West into their new home and as a result they are being targeted by the recriminations of Western populist parties: they take the jobs of the natives, work for lower wages, increase criminality. In these conditions, can populist parties from Western Europe co-operate with their Eastern counterparts? Do the voters of populist parties have a similar profile, or even is there a resemblance between the followers of all populisms in history, is there a generic people of populism who would be the cornerstone of this sociopolitical construct?

We shall strive to answer in the first place the last question, as it is the most general. The answer cannot help being ambivalent. Yes, because the critical mass of populism has always been represented by the losers of a socio-economic process of transformation. No, because there is an essential change of the target: 'ancient' populism (until WWII) defended labour (peasants, farmers, industrial workers) against the idle wealthy, the oppressive 
Issue no. $23 / 2017$

government and huge capital (opposing the small people to the big), modern populism is the voice of a middle people discontent with the "privileges" conceded to the poorest: the average rebel against the "excessive" welfare conceded to the smallest (including the refugees).

Modern populism is perhaps older than one might think. As soon as 1935, US social scientist David J. Saposs (p. 393) interpreted "Fascism being the extreme expression of middle-classism or populism".

The audience of today's populism are the losers of modernization, those who risk the deterioration of their status because of social transformation, whatever the reasons of this transformation (globalization in Western Europe since the 1980's, transition in Central and Eastern Europe from the fall of communism in 1989 until the accession of these countries to the EU in 2004 and respectively 2007 for Bulgaria and Romania, 2014 for Croatia).

The EU accession of CEE countries has levelled the field of populism in many aspects. The populist vote is a protest vote. The surveys conducted EU-wide have revealed the profile of populist voters is more or less the same across Europe: nativist, authoritarian personalities, Europhobic (more so in Western Europe) and anti-immigration (in the "old Europe)/ xenophobic or hostile to ethnic minorities (in the "new Europe"), fearing modernization and discontent with politics.

The more someone is displeased with politics, the greater the odds s/he voted for a populist party. When the messages conveyed by mainstream political parties (e.g. the need for austerity policies in Greece after the financial crisis) are too similar and the ideological cleavages almost obliterated, an avenue opens for populist movements. Crisis fuels their appeal. Populism has been perceived as a disease of representative democracy from the very first conference in 1967 where Peter Wiles (1969, p. 166) deemed it "A Syndrome, not a Doctrine". If Central and Eastern European democracies are younger then Western ones, the disenchantment with the national political establishment reaches record heights in the region. Only $33 \%$ of Romanians trust their government and 27\% their Parliament, while for Poland the corresponding figures stand at 33\% and 25\%, much lower than the EU28 average (Eurobarometer 87 Spring 2017).

When it comes to the anti-immigration stance, Eastern populists are as radical as the Western ones. They echo their national public opinion, with 11 out of the 15 most hostile countries to immigration from outside the EU hailing from the former communist bloc, ranging from a record $83 \%$ of negative opinions in Latvia to Romania's 59\% (Eurobarometer 
Issue no. $23 / 2017$

86, Autumn 2016). The only "intruders" are countries highly impacted by the refugee crisis (Greece, Italy, Malta). As the Visegrad group (Czech Republic, Hungary, Poland, Slovakia) refused to take part in the EU's refugee relocation scheme, domestic support for this position was overwhelming.

Central and Eastern European parties are seldom hard Eurosceptics (save for Jobbik, Ataka and Order and Justice), because the image of the EU as source of prosperity is still dominant in the region. However, the Fidesz and the PiS, as ruling parties, have joined efforts at EU level to convey a political message that stands in defiance of the liberal democratic model and have thus become models for Western populist parties which, though theoretically more hostile to the EU, lack the means to harm EU policies and can only express tough criticism in the European Parliament.

In conclusion, there is no divide between Eastern and Western European populism, only minor contextual differences.

\section{Is there a populist momentum in the EU?}

In the final part of this paper, the time has come to answer the initial question: can we speak of a populist momentum in the EU? Is there a threshold or an indicator to assess it?

Populist parties have posted big wins in the 2014 European elections. The Fidesz, Smer-SD, UKIP, SYRIZA, the Danish People's Party, the National Front emerged as victors, the PiS was very close to do so and scored a very high result, Sinn Fein came second close enough to the winner and the 5 Star Movement rose to more than 20\%. However, many of these parties drew lower support in the subsequent national legislative elections, most notably in France, UK and Ireland. Their scores at the EP elections are not necessarily a relevant indicator, as these tend to be a single-issue ballot: pro/ anti-EU. As in many countries the populists monopolize the Europhobic discourse (though not so in France, Italy and the UK), they took advantage of this unique cleavage to maximize their gains.

2014 saw a strong anti-establishment vote, with Eurosceptic parties taking roughly a quarter of the EP seats. As there is no united Eurosceptic front in the Parliament, but also because of the historical tradition of bi-partisan co-operation between the major political groups (EPP and S\&D) to reach majority on important issues, the populists, despite their numbers, remain marginal. Though no causal relationship can be drawn, since spring 2014 and the last EP elections, trust in the EU has soared at European level at $42 \%$ in spring 2017, up from 31\% (source: Eurobarometer). 
In our view, if we are to speak about a populist momentum in present day Europe, it is not necessarily by virtue of the cumulated populist score. EU28 is radically different from the EU15, where populist parties also achieved significant success. The major factor is the new status that populism has managed to acquire following the 2004 and 2007 successive EU enlargements. In 1999, when Jörg Haider's Freedom Party (FPÖ) entered government following a strong display in the elections, as the junior partner despite a slightly better score compared to the ÖVP, the other 14 members of the EU imposed diplomatic sanctions on Austria in February 2000 (they were only lifted in September 2000). In Western Europe, populist parties have been associated with the extreme right and subjected to a cordon sanitaire, which is still in place in France towards the FN or in Germany towards the AfD.

These pre-emptive sanctions would be unthinkable today, with populists like Orbán Viktor, Robert Fico or Beata Szydlo sitting in the European Council.

In Central and Eastern Europe, populism has become mainstream and in some countries, like Slovakia, populist parties have dominated the political stage in the long run. As a conclusion, if there is now a populist momentum in the EU, it is mostly a consequence of the enlargements to the East. The different political culture in some of these countries has brought the populists to the table. And they are here to stay.

\section{Bibliography}

- ADAM, R. (2016) National-populisme en Roumanie. Tradition et renouveau postcommuniste. Brussels: Ph. D. dissertation defended at the Universite libre de Bruxelles.

- AlbertaZZI, D./ McDONNEL, D. (2007) Twenty-First Century Populism: The Spectre of Western European Democracy. New York \& London: Palgrave Macmillan.

- CANOVAN, M. (1981) Populism. New York \& London: Harcourt Brace Jovanovich.

- HERMET, G. (2001) Les populismes dans le monde : une histoire sociologique XIX $-X X^{e}$ siècle. Paris: Fayard.

- IONESCU, G./ GELlNER, E. (eds.) (1969) Populism. Its Meanings and National Characteristics. London: Weidenfeld and Nicolson.

- JAgUARIBE, H. (1967) Problemas do desenvolvimento latinoamericano. Rio de Janeiro: Civilizaçao Brasileira. 
- LACLAU, E. (1977) Politics and Ideology in Marxist Theory: Capitalism-FascismPopulism. London: Verso.

- LAClAU, E. (2005) On Populist Reason. London \& New York: Verso.

- LIPSET, S.M. (1960) Political Man: The Social Bases of Politics. New York: Doubleday.

- SAPOSS, D.J. (1935) The Role of the Middle Class in Social Development: Fascism, Populism, Communism, Socialism. In: Economic Essays in Honor of Wesley Clair Mitchell. New York: Columbia University Press, pp. 393-424.

- TAGUIEFF, P.-A. (2001) Populisme, nationalisme, national-populisme. Réflexions critiques sur les approches, les usages et les modèles. In: DELANNOI, G./ TAGUIEFF, P.-A. (sous la dir.) Nationalismes en perspective. Paris: Berg International, pp. 303-398.

- WILES, P. (1969) A Syndrome, Not a Doctrine: Some Elementary Theses on Populism. In: IONESCU, G./ GELLNER, E. (eds.) (1969) Populism. Its Meanings and National Characteristics. London: Weidenfeld and Nicolson, pp. 166-179.

\section{ELECTRONIC REFERENCES}

- European Parliament elections: http://www.europarl.europa.eu/elections2014results/en/election-results-2014.html [Accessed 15/09/17].

- National legislative elections: http://www.parties-and-elections.eu/ [Accessed 15/09/17]. 